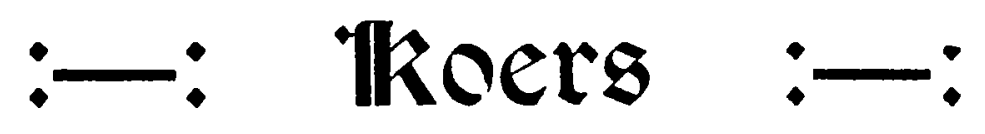

TWEEMAANDELIKSE TYDSKRIF

\begin{tabular}{llr}
\hline DEEL XXI & Desember 1953 & No. 3 \\
\hline
\end{tabular}

\title{
ORIËNTERING.
}

\section{Teologie en Wysbegeerte.}

Gedurende die afgelope eeu vind in die Westerse denke 'n omvattende en diepgaande kentering plaas. Aan hierdie kentering in ons tydsgees neem gelowiges en ongelowiges wetend-onwetend, willend-onwillend, saamgaand-hervormend deel. In hierdie kentering neem die vertroue op die verstand en die rede van die mens (rasionalisme) af en gee die mens hom al meer oor aan wat nie deur sy verstand of rede beheers kan word nie (irrasionalisme). Ons tref hierdie en die volgende kenmerke van ons tydsgees in byna alle wetenskappe aan, ook in die natuurwetenskappe wat so intens rasionalisties in opset was. Die meganiese opvatting van dinge wat alles uit die kleinste bestanddele wil verklaar, bv. uit atome (in die natuur) en uit individue (in die menslike samelewing) wyk vir 'n holiese beskouing wat alles, die natuur, die mensheid, die heelal as 'n geheel wil sien en alles vanuit 'n geheelsperspektief wil benader). As derde kenmerk van ons hedendaagse denke wil ek noem die vertroue op en die verheerliking van 
die daad wat sukses het, van die skeppende doen en dat die waarde en die sin van die lewe nie meer in waarheid, wette en norme gevind word wat deur die verstand ontdek word nie, maar in die alle verskeidenheid oorbruggende dinamiek, in die kragvolle, die eksistensiële, in dit wat werklik is, word en ontwikkel, in die prestasies wat die mens met sy handelinge bereik, in mens-wording deur self-transsendensie en selfskepping.

Hierdie kentering in die huidige Westerse tydsgees maak opnuut en op 'n nuwe wyse die belangstelling gaande oor die eeue-oue strydvrae aangaande die verhouding van geloof en wete en van teologie en wysbegeerte asook aangaande die vraag oor die moontlikheid en bestaansreg van 'n Christelike wetenskap. En moenie dink nie dat die stryd om hierdie vraagstukke uitsluitelik akademies van betekenis en karakter is nie. Die posisiekeuse wat jy in hierdie strydtoneel inneem (en ook die van ander) raak jou (en ander se) houding en verhouding tot God en wêreld, tot die kerk en die ander samelewingskringe, tot godsdiens en die hele kulturele lewe.

Om die belang hiervan wil ek die huidige worsteling van die geeste i.v.m. bogenoemde strydvrae in enkele lyne uitstippel-al is dit dan ook op enigsins ,inventaris-agtige" wyse. Dit gee die leser 'n (alhoewel onvolledige) oorsig oor die oorlogsfronte en belangrikste slagvelde van die

\section{REDAKSIONEEL.}

Die Redaksie het besluit om diskussie oor wat in KOERS verskyn toe te laat. Die meningsverskille moet egter onpersoonlik en wetenskaplik gestel word en so kort en kragtig as moontlik.

huidige stryd om die genoemde probleme; en dit bied die belanghebbende, asook belangstellende leser die geleentheid om hom in hierdie strydtoneel beter te orisnteer.

Die spanninge om die bogenoemde strydvrae kan u duidelik beluister o.a. in wat deur eksistensialistiese wysgere (o.a. soos Jaspers, Loen en Ma:cel en op negatiewe wyse Heidegger en Sartre), deur holistiese kreatief-evo:usionistiese wysgere (soos o.a. Alexander, Boodin en Whitehead), deur dialektìse teoloë (soos o.a. Barth, Brunner, Heim en Gogarten) en 
deur--om huile as $\mathrm{n}$ aparte groep te stel-die Rooms Katolieke teoloë en wysgere (soos o.a. Brehier, Mandonnet, Noël, Lubac, Gilson, Maritain en Blondel) gestel word.

Sommige skei teologie en wysbegeerte radikaal van mekaar (soos o.a. Barth, Brehier, Mandonnet en Ovink); lg. stel dat wat aan 'n gedagte Christelik is, nie wysgerig is nie en dat wat daaraan wysgerig is, nie Christelik is nie. Ander soos o.a. Gilson, Maritain, Blondel en Loen wil teologie en wysbegeerte intiem verbind; Blondel sien die verbintenis selfs as 'n simbiose, as 'n samelewing soos in 'n egtelike verbintenis, maar wil tog beide skerp onderskei; Loen verbind weer beide so intiem dat hy self nie presies weet nie of hy met wysbegeerte of met teologie besig is en ondermyn sodoende die selfstandigheid van elk; interessant is Loen se stelling dat as 'n Christelike wysbegeerte ('n wysbegeerte wat vir die Openbaring oop staan) onmoontlik is, elke wysbegeerte onmoontlik is.

In hierdie verband is dit merkwaardig dat wysgere anders en meer as voorheen rekening hou met wat teoloë en teoloë met wat wysgere sê; dit is asof die mure wat in die laaste eeue tussen die wysbegeerte en die (veral positief Christelike) teologie ontstaan het, begin omval en die teëstelling 'n ander word en wel só dat mens teoloë en wysgere tesame ander teoloë en wysgere sien bestry.

Lesers wat enigsins op hoogte wil kom met die huidige spanninge i.v.m. die genoemde probleme sou die volgende oriënterende (by Pro Rege voorhande) werkies kon lees: Dr. J. J. Louët Feisser se De Huidige verhouding tussen Theologie en Wijsbegeerte (waarin o.a. aandag gegee word aan die Rooms Katolieke denkers, aan K. Barth en aan A. E. Loen) en Filosofie en Geloof (No. 7 van Nederlands Gesprek Centrum) waarin J. A. J. Peters, A. G. M. van Melsen, J. G. van der Ploeg, J. P. van Praag, G. Brillenburg Wurth, Ph. Kohnstamm, J. L. Witte en Th. L. Haitjema (denkers van uiteenlopende rigtings en sowel teoloë as wysgere) oor bogenoemde probleme 'n onderlinge gesprek voer. Meer gevorderd is M. C. Smit se Christendom en Historie in die huidige Rooms-Katholieke Geschied-beschouwing en Philosophia Reformata, 2e en 3e kwartale 1953 waarin Dooyeweerd in Frans sy sienswyse i.v.m. 'n Christelike wysbegeerte met die van ander konfronteer en Zuidema Barth se opvatting aangaande die verhouding van teologie en wysbegeerte aan indringende kritiek onderwerp.

En ons? Wat geskied in ons eie geledere?

Oor die bestaansreg van 'n Calvinistiese wysbegeerte is ons dit eens al bou ons aan hierdie wetenskap nie oral eners nie. Maar oor die onderskeid en verhouding van teologie en wysbegeerte verskil ons. Volgens 
die „Wysbegeerte van die Wetsidee” (i.e. veral Dooyeweerd, Vollenhoven en Popma) is teologie (nes sterrekunde en sosiologie) 'n vakwetenskap, al is dit die hoogste van die vakwetenskappe en is wysbegeerte daarenteen universele wetenskap. Ondergetekende egter stem o.a. met $\mathrm{H}$. Bavinck saam dat teologie (in Calvinistiese en nie in skolastiese sin verstaan nie): koningin van die wetenskappe en dus ook van die wysbegeerte is, en hoegenaamd geen vakwetenskap is nie. Hierdie beskouing van hom word in die Gereformeerde Vaandel ,Jun. 1935, deur ds. P. de B. Kock en is in Correspondentiebladen van de Vereeniging voor Calvinistische Wijsbegeerte, Amsterdam XIII, 1 deur dr. K. J. Popma aan kritiek onderwerp. Oor hierdie vraagstuk sal sowel in die Gereformeerde Vaandel as in Koers later bydraes verskyn; en dan is dit wel van belang om die gronde asook die redes te ontleed waarom een Calvinis teologie bo alle wetenskappe, ook bo die wysbegeerte, plaas terwyl 'n ander Calvinis wysbegeerte tot universele basis van alle wetenskappe, ook van die teologie maak-en beide dit doen o.a. veral uit Skriftuurlike motiewe.

Dat Gereformeerde teoloë en Calvinistiese wysgere kritiese aandag sal skenk aan wat andersdenkendes op die genoemde strydtoneel bied en aan die stryd daadwerklik sal deelneem, spreek vanself. Maar een vraag moet van my hart af. Ek meen dat Calvinistiese wysgere hier in ons land, in Holland en in Grand Rapids wel op hoogte is van wat die Gereformeerde teologie leer. Maar gee Gereformeerde teoloë oor die drie genoemde kontinente wel aandag of wel voldoende aandag aan wat Calvinistiese wysbegeerte bied? Is die belangstelling nie te eensydig nie i.p.v. wedersyds en kan ons onderling tot ' $n$ bevredigende oplossing kom i.v.m. genoemde vraagstukke (wat geen van beide eintlik alleen kan aanpak nie), as Gereformeerde teoloë intellektueel so (betreklik) geïsoleerd van Calvinistiese wysgere lewe? Of het ek dit mis? Aan die ander kant, staan Calvinistiese wysgere dikwels nie te krities teenoor die Gereformeerde teologie nie?

Dat ons mekaar wedersyds nodig het en dat wanneer die een hom van die ander isoleer, hy dit doen tot sy eie skade, spreek vanself en wel omdat die waarheid 'n eenheid is. Samewerking is ook hier dure plig. 